\title{
前立腺肥大症の薬物治療最前線
}

\author{
河邊香月
}

\section{Latest Frontiers in Pharmacotherapy for Benign Prostatic Hyperplasia}

\author{
Kazuki KaWABE \\ Tokyo Teishin Hospital, 2-14-23, Fujimi, Chiyoda-ku, Tokyo 112-8798, Japan
}

(Received October 18, 2005)

\begin{abstract}
$\alpha_{1}$-Adrenoceptor antagonists, called $\alpha_{1}$-blockers, are the first-line treatment for lower urinary tract symptoms associated with benign prostatic hyperplasia (BPH). Nonselective $\alpha_{1}$-blockers like prazosin were mainly used in the past, but prostate-specific $\alpha_{1}$-blockers such as tamsulosin or naftopidil are now the mainstream agents for the management of $\mathrm{BPH}$, based on the function of $\alpha_{1}$-adrenoceptor subtypes. Recent studies on voiding dysfunction have clarified the association between $\mathrm{BPH}$ and overactive bladder $(\mathrm{OAB})$, underlining the use of $\mathrm{OAB}$ treatment in the management of $\mathrm{BPH}$, inducing the simultaneous administration of antimuscarinic agents. Every aspect of diversified BPH symptom can be controlled individually in a short period.
\end{abstract}

Key words_ - benign prostatic hyperplasia; lower urinary tract symptoms; overactive bladder; $\alpha_{1}$-blockers; antimuscarinic agents

\section{1.はじめに}

前立腺肥大症 (benign prostatic hyperplasia; BPH) の症状はよく知られているように，腫大した前立腺 (benign prostatic enlargement; BPE) によって膀胱 頸部・尿道が圧迫され（bladder outlet obstruction; $\mathrm{BOO})$, 尿が出にくくなつて, 残尿感, 頻尿, 排尿 困難などの下部尿路症状（lower urinary tract symptoms； LUTS）が現れるものを言う。本稿では， $\mathrm{BPH}$ と BPE は以上のように区別して使用する.

$\mathrm{BPH}$ の症状を詳細かつ広範に記載し, 疾患単位 （診断名）を確立させれば，治療法はおのずと決ま るといつた手法, すなわち診断・治療の標準化はど の疾患についても取られてきた。 BPH においても 例外ではなく，2001 年には診療ガイドラインが発 行されている。しかし BPH の症状は多彩であり, 特に近年，過活動膀胱（overactive bladder; OAB） の概念が出てきてからは， BPH を画一的に扱うの ではなく, BPHの持っているいろいろな「姿」に 対し，それにふさわしい「注文服」を作ること，す なわち個別化が泌尿器科医に要求されるようになつ てきた。これがいわゆるテイラーメイド・メディシ

東京逓信病院 (T112-8798 千代田区富士見 2-14-23)

e-mail: kkawabe@tth-japanpost.jp
ンであり，現在はこの方向へ向かうための経験の集 積や実験が精力的に行われている段階と言える.

一方で，BPH は良性疾患であるため，前立腺癌 などのように直接生命に関わる病気ではない。誤解 を恐れずにあえて言うならば，尿閉などによる苦痛 や尿路の器質的変化を来さない限り，手術はできる だけ避け，QOL を改善する治療法を考えればよ い. 現在は様々な薬剤あるいは治療法が開発されつ つあり, 臨機応変な対応ができる時代になつている からである。

2. 前立腺肥大症とは

$\mathrm{BPH}$ とは, BPE, BOO, LUTS という 3 つの要素 が混在して起こる症候群で，古くは Hald，新しく はAbrams が改定したダイアグラムによって，この 関係を説明できる（Fig. 1)。典型的には 3 つの輪 が重なつたところにみられるように，前立腺は大き $<(\mathrm{BPE})$, 尿は出に<< (BOO), 膀胱刺激症状 として残尿感，頻尿（LUTS）などすべて揃ってい るものでは，診断に迷うことはない.

問題は，これら 3 つの要素が揃つておらず，1つ 又は 2 つが什てる場合であろう。例えば BOO とLUTS が揃つていながら，BPEが認められない 場合は prostatism あるいは膀胱頸部硬化症と診断 


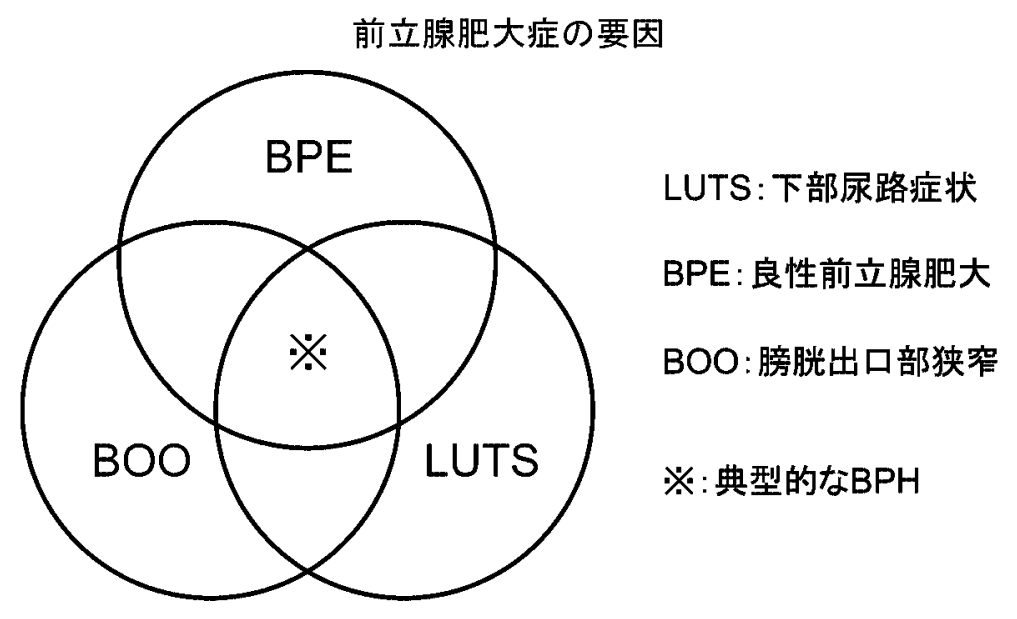

Fig. 1. Triangle of BPH (Abrams)

されていた. しかしながら Abrams のダイアグラム ではこのようなタイプも BPH として扱っている.

他方，BPEとLUTS が著明であって，BOOが証 明できない症例については，BPH として扱うこと には異論はない。しかしこのような場合は BPH に 対する手術療法のゴールド・スタンダードである経 尿道的前立腺切除術（TURP）を行っても症状の改 善が得られない場合があることが知られている。 そ こで TURP を行う前に膀胱内圧尿流同時測定を行 つて BOO を確かめるべきかどうかが古くから議論 の絶えない問題となっている，確かに，BOO が明 らかでないもの，つまり BPE とLUTS だけの場合 は，TURP の結果が思わしくないという報告があ る一方, TURP に反応しない症例は，あるとして もその頻度は少ないのであるから，わざわざ侵襲的 な検査をする意味がないと考える泌尿器科医もお り，はなはだ controversial である。ささに，BPE のみ，又はLUTS のみを呈する場合はどのように 考えたらよいかの問題がある. 最近はLUTS のみ でも BPH/LUTS 又は aging male LUTS と表記し て, 従来の BPH に相当するものとして扱う考え方 が主流になっているようである。この問題の解決は LUTS の発症機序を解明して初めて結論が出ると思 われる. LUTS の pathophysiologyは，近年徐々に 解明されつつあり, BPH の治療戦略もさらに理論 化・個別化していく可能性がある.

\section{LUTS とは}

下部尿路症状（LUTS）は，蓄尿相，排尿相，及 び排尿後相にみられる症状からなり，それぞれ分け
Table 1. International Prostate Sympton Score (I-PSS) 国際前立腺症状スコア (I-PSS)

\begin{tabular}{ccc}
\hline \hline 症 状 & 旧分類 & \multicolumn{1}{c}{ 分 類 } \\
\hline 残尿感 & 閉塞症状 & 排尿後症状 \\
昼間頻尿 & 刺激症状 & 蓄尿症状 \\
尿線途絶 & 閉塞症状 & 排尿症状 \\
尿意切迫感 & 刺激症状 & 蓄尿症状 \\
尿勢低下 & 閉塞症状 & 排尿症状 \\
腹圧排尿 & 閉塞症状 & 排尿症状 \\
夜間頻尿 & 刺激症状 & 蓄尿症状 \\
\hline
\end{tabular}

て考えると便利である. BPH の重症度を定量的に 評価する指標として作られた，国際前立腺症状スコ ア (I-PSS; International Prostate Symptom Score) では, このうち蓄尿相から 3 つ, 排尿相から 3 つ, 排尿後相から 1 つ, 合わせて 7 つ質問を選び，そ れを点数化している（Table 1)。このスコアについ てはよく知られているので, 今回は詳しく触れな い. 妥当性, 再現性などに優れているものの, $\mathrm{BPH}$ の他覚的所見などの要因とかならずしも相関 しないこと, 最近の傾向としては, 高齢男性の LUTS は無条件でBPH と診断すること，あるいは “Prostate”と言う表記があるにも関わらず女性で もこのスコアが高いことがある（もちろん BPH で はない!）ことなどが問題である。そこで, I-PSS のみならず QOL index, 最大尿流率, 残尿量, 前 立腺の大きさなどと組み合わせて BPH の重症度判 定をする工夫がなされている.11

LUTS は, 2002 年の国際禁制学会 (International Continence Society；ICS）で定義し直され，その際， 
$\mathrm{OAB}$ の概念が導入された。 ${ }^{2)}$ その中で， $\mathrm{BPH} も$ $\mathrm{OAB}$ の原因となり得ると考えられ，その関連や病 因を巡って, 活発な研究や議論が繰り広げられた. 一筋縄では解決できない, 大きな問題を抱える一方 で, 薬物療法への新しい道を展開することにもなつ た.

\section{4. 補完的薬物療法}

BPH の pathogenesis が今より未解明だった頃, 経験的に薬物療法が試みられて一定の効果が得られ ていた。 今でも，ヨーロッパ，特にドイッ，イタリ ア，スウェーデンなどで草木の抽出物による治療 (phytotherapy) が行われてきた。わが国では漢方 薬の八味地黄丸, 植物抽出物, エビプロスタット, セルニルトン，アミノ酸製剤のパラプロストなどが 使われている。アメリカでも, 補完代替医療 (Complementary Alternative Medicine; CAM) とし て植物製剤がリバイバルし，最近ノコギリヤシが注 目を浴びている. ${ }^{3)}$ 従来，ノコギリヤシは，アンド ロゲン受容体の結合阻害, 前立腺上皮のアポトーシ スの促進など前立腺肥大抑制作用が報告されてお り, ${ }^{4)}$ 最近ではラットにおいて $\alpha_{1}$ 受容体やムスカリ ン受容体の阻害作用も報告され, ${ }^{5)}$ 排尿障害改善作 用における作用機序が徐々に解明されつつある。す なわち，まだ不十分ながら，唯一 EBM の枠の中に 入った「生薬」と言える.

筆者個人としては, これらの補完代替医療につい ては, 有用性が理論的に証明されれば選択肢の $1 \supset$ であると考えている. 特にノコギリヤシはユニーク な作用を持っており，今後より純粋な作用物質が明 らかになることに大きな期待を寄せている.

\section{5. $\alpha$ 遮断薬の登場}

BOO には，機械的閉塞（前立腺が物理的に尿の 排出を妨げる）と機能的閉塞（前立腺平滑筋が収縮 して機能的に尿道を狭める）があることが知られて いる．後者の要素はちょうど細小血管が収縮して血 流を阻害し，血圧が上がるのと似ている。したがつ て，平滑筋を弛緩し，尿道を緩めることによって尿 流をスムーズにすることが可能で，降圧薬に $\alpha$ 遮 断薬を用いたように，BPH にも $\alpha$ 遮断薬が使われ るようになった。

20 年ほど前から， $\alpha_{1}$ 受容体サブタイプの機能の 研究が進み, 前立腺の収縮に関与する $\alpha_{1}$ 受容体は 主に $\alpha_{1 \mathrm{~A}}$ サブタイプであることが分かり，血管に多
く存在する $\alpha_{1 \mathrm{~B}}$ サブタイプは, 排尿障害にはあまり 関与していないことが判明した。 そして世界に先駆 けて初めて, わが国で前立腺特異的な，すなわち血 圧には影響の少ない $\alpha_{1}$ 遮断薬が創製された。これ が夕ムスロシンで, 日本ではハルナールとして 10 年以上前に発売されており (Table 2)，世界中で BPH の第一選択薬として最も広く使われている. タムスロシンの登場により, アメリカでも泌尿器科 医のドル箱であった TURP が激減したことは周知 の事実である。 また最近では, BPH の症状のうち 蓄尿症状といわれる頻尿, 尿意切迫感等には, $\alpha_{1 \mathrm{D}}$ サブタイプが $\alpha_{1 \mathrm{~A}}$ よりも深く関係しているらしいと 言われている. ${ }^{6)} \mathrm{BPH}$ にみられる OABにも，神経 節の $\alpha_{1 \mathrm{D}}$ 受容体が関与しているようである.

多分に宣伝的要素が強いとはいえ，わが国で $\alpha_{1 \mathrm{D}}$ に比較的親和性が強い薬剂（ナフトピジル）が開発 されたこともあって（Table 2), 7) BPH の蓄尿症状 にはナフトピジルがタムスロシンに勝るという報告 が本邦の学会では多いようである。実際， $\alpha_{1 \mathrm{D}}$ ノッ クアウトマウスでは正常群と比べて排尿回数が減少 し, 1 回排尿量が増加していたことから $\alpha_{1 \mathrm{D}}$ は蓄尿 症状により強く関係することが報告されている. ${ }^{8)}$ しかしながら, 最近のランドマイズド・スタディに よると, タムスロシン, ナフトピジルの間で, 排尿 症状, 蓄尿症状とも効果に差がないとの報告もあ り, 9) 最終的結論はいまだ出ていない. 参考まで に, 日本において開発あるいは使用されている代表 的な $\alpha_{1}$ 遮断薬とそのサブタイプ選択性を Table 2 及び Table 3 に示す. 7,10,11)

今のところ，世界的なコンセンサスは，各種 $\alpha_{1}$ 遮断薬は相互に臨床的効果の差はなく, 副作用の少 なさで, 選択的な $\alpha_{1}$ 遮断薬がやや勝っていること

Table 2. $\alpha_{1}$ Blockers for BPH

$\mathrm{BPH}$ に使用される $\alpha_{1}$ 遮断薬

\begin{tabular}{ll}
\hline \hline 一 般 名 & \multicolumn{1}{c}{ 商 品 名 } \\
\hline プラゾシン & ミニプレス \\
テラゾシン & ハイトラシン, バソメット \\
タムスロシン & ハルナール \\
ナフトピジル & フリバス, アビショット \\
アルフゾシン & 海外のみ（日本 : PII $)$ \\
ドキサゾシン & 海外のみ \\
シロドシン & 現在申請中 \\
\hline
\end{tabular}


になっている．また，前立腺の収縮すなわち機能的 な尿道閉塞に深く関与しているのは $\alpha_{1 \mathrm{~A}}$ サブタイプ であることは周知の事実である。最近， $\alpha_{1}$ 遮断薬 で， $\alpha_{1 \mathrm{~A}}$ サブタイプに特に強い選択性を持つ $\alpha_{1 \mathrm{~A}}$ 遮 断薬（シロドシン：KMD-3213）ができており (Table 3),11) プラセボを対照とした二重盲検試験 において排尿症状 (残尿感を含む)の改善に加えて, 蓄尿症状にも幅広く有効性を示したことは， $\alpha_{1 \mathrm{D}}$ が 蓄尿症状に強く関与しているという説をかならずし もサポートしない点で興味深い（Fig. 2). 12)

現在までに分かっていることは，BPH になると $\alpha_{1 \mathrm{~A}}$ 及び $\alpha_{1 \mathrm{D}}$ サブタイプが増加することである， $\alpha_{1 \mathrm{~A}}$ は排尿症状に， $\alpha_{1 \mathrm{D}}$ は蓄尿症状により強く関係する とすれば，患者によって排尿症状と蓄尿症状の程度 に違いがあるのは， $\alpha_{1 \mathrm{~A}}$ と $\alpha_{1 \mathrm{D}}$ サブタイプの分布に

Table 3. Selectivity of $\alpha$-Blockers for $\alpha_{1}$ AR Subtypes $\alpha_{1}$ 受容体サブタイプに対する $\alpha_{1}$ 遮断薬の選択性

\begin{tabular}{|c|c|c|}
\hline 一 般 名 & $\alpha_{1 \mathrm{~A}}$ & $\alpha_{1 \mathrm{D}}$ \\
\hline プラゾシンal & 1.5 & 3.8 \\
\hline テラゾシンb) & 0.38 & 1.1 \\
\hline タムスロシン $a)$ & 15.3 & 4.6 \\
\hline ナフトピジルc) & 5.4 & 16.7 \\
\hline シロドシンa) & 583 & 10.5 \\
\hline
\end{tabular}

$\alpha_{1 \mathrm{~B}}$ に対する親和性を 1 として算出 $a$ ) Shibata K. et al., Mol. Pharmacol., 48 (2), 250-258 (1995), b) Foglar R. et al., Eur, J. Pharmacol., 288 (2), 201-207 (1995), c) Takei R. et al., Jpn. J. Pharmacol., 79 (4), 447-454 (1999).
個人差があるからとも考えられる。これが正しいと すれば，前立腺の組織を一部生検で採って，その $\alpha_{1}$ 受容体サブタイプの mRNA 発現を調べれば，個 々の遺伝子発現に合わせた, いわゆるテイラーメイ ド・メディシンが適用される可能性がある. 今のと ころこれは研究段階に過ぎず，統一見解は得られて いない。臨床的な症状と，遺伝子などの分子生物学 的情報がそう単純に結び付くか, 今後の研究課題と 言える.

むしろ $\alpha_{1}$ 遮断薬による治療の問題点は，BPH と いう疾患の性質からみても長期に使用しなければな らないので，(1)経済的に見合うか，(2)手術に移行す る例を最初から予見できるか，に集約できる。経済 的には，10 年のスパンでみれば TURP のほうが有 利である。しかし， BPH は全例手術を要する訳で はなく, 周術期の苦痛や痛み, 出血, さらに術後の 尿道狭窄，勃起機能の低下（ED）などを考慮する と，不要な手術を避けられればそれに越したことは ない。.となれば， $\alpha_{1}$ 遮断薬などを使いながら対症 的に維持できるか，すなわち最終的な手術の要否を 予見することが最も重要となる。

筆者らは, ${ }^{13)}$ I-PSS, QOL スコア, 最大尿流率 $\left(\mathrm{Q}_{\max }\right)$ などのパラメターを指標にして $\mathrm{BPH}$ を重 症度分類すると，重症以外では手術移行率が少な く，かなり長期に $\alpha_{1}$ 遮断薬（タムスロシン）で維 持できることを観察している（Fig. 3)。また，最

\section{排尿症状 - 蓄尿症状に対するシロドシンの効果}

排尿症状

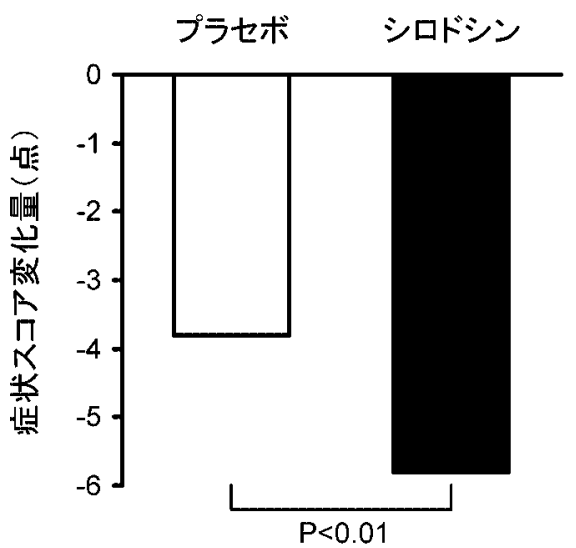

蓄尿症状

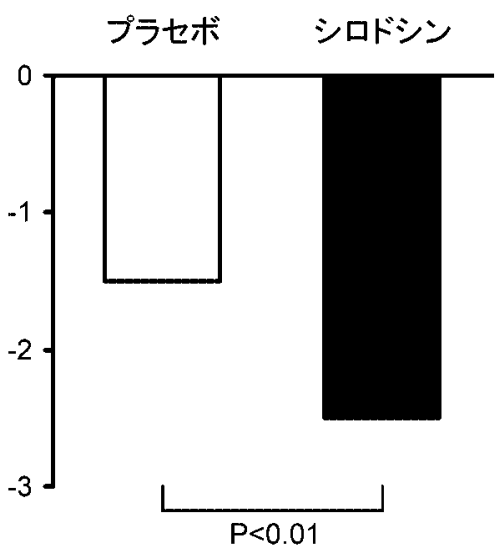

投与終了時における観察期からの変化 $(t$-test $)$

Fig. 2. Effect of Silodosin 
最大尿流率 $\left(Q_{\max }\right)$ から見た重症度別手術非移行率

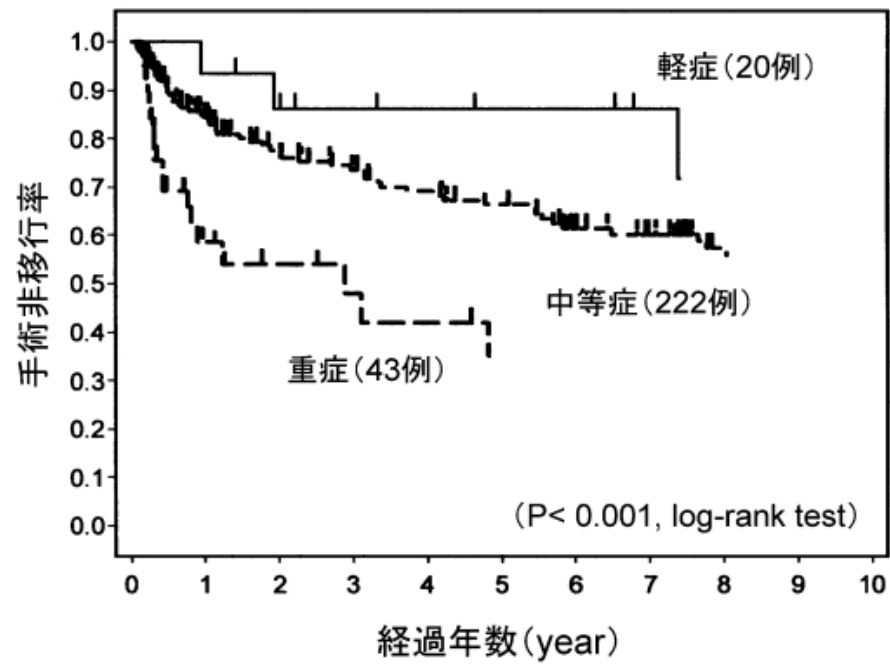

重症度分類 $\left(Q_{\max }\right)$

軽症: $\geqq 15 \mathrm{~mL} /$ 秒

中等症: $\geqq 5 \mathrm{~mL}$ 秒

重症: $<5 \mathrm{~mL}$ 秒

Fig. 3. Transter to Invasive Treatments in Severities of Maximum Flow Rate $\left(\mathrm{Q}_{\max }\right)^{13)}$

近の学会報告でも, I-PSS $\geqq 20$ かつ前立腺体積 $\geqq 30$ $\mathrm{ml}$ の患者では他の患者に比べ手術移行率が高いこ とが報告されている. ${ }^{14)}$ また I-PSS が手術移行率の 最もよい指標であるとする研究者もある. ${ }^{15)}$ 実際の 臨床では $\alpha_{1}$ 遮断薬だけで，しかも休薬しても悪化 しない例も多いので，手術をしなければならない例 は少ないのではないかと思われる，今後，薬剤のみ でコントロールすることができる症例が予見できる ようになり，さらに薬物療法の幅が広がると思われ る. 泌尿器科医の中には薬物療法の発展に鑑み, 尿 閉などを経験しない限り TURP は勧めないと言う 医師もいるほどである。TURP は BPH の手術には ゴールド・スタンダードであっても， BPH 治療の ゴールド・スタンダードではないと言えよう.

LUTS と ED (Erectile Dysfunction) 関連はよく 知られたところであり， $\alpha_{1}$ 遮断薬によるLUTS の 改善は，同時に ED の改善をもたらすことが報告さ

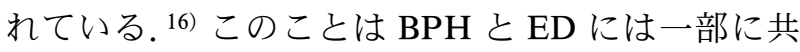
通のメカニズムが働いていることを示唆する。一 方, 時に $\alpha_{1}$ 遮断薬は可逆的な射精障害を引き起こ すことがあり，タムスロシン，シロドシンは他の $\alpha_{1}$ 遮断薬に比べ射精障害を来し易いと言われてい る. 実際, 海外では夕ムスロシン開発時に用量依存 的（〜0.8 mg）な射精障害発現率の増加が観察され ている. ${ }^{17)}$ 幸いわが国ではそれほど多い訴えではな い. 最近では, タムスロシン $(0.2 \mathrm{mg})$ により逆行 性射精ではなく射精量の減少（射出障害）が観察さ
れたとの報告もある. ${ }^{18)}$ さらに，わが国では抗男性 ホルモン薬が BPH の治療薬（酢酸クロルマジ） ン，アリルエストレノール）として使われており， これらは性欲低下や ED を引き起こし易い。患者と 相談の上，注意して使うべきものであろう.

さらに興味あることに， $\alpha$ 遮断薬を長期間投与す ると従来の認識と異なり, 前立腺平滑筋の増殖を抑 える作用があることが分かってきた. ${ }^{19)} \alpha_{1}$ 遮断薬が 前立腺の大きさに影響を与えることなく， $\alpha_{1}$ 受容 体サブタイプの発現に変化をもたらすようである.

前立腺への男性ホルモンの作用を阻害する $5 \alpha$-RI (reductase inhibitor) と， $\alpha_{1}$ 遮断薬を併用しても相 乗効果は認められないという Lepor らのショッキ ングな報告 ${ }^{20)}$ 以来， $5 \alpha$-RI の使用はやや下火となつ た.しかし，これに反するデータ21)も多く存在し， 米国前立腺肥大症薬物治療研究（MTOPS）では, ドキサゾシン $\left(\alpha_{1}\right.$ 遮断薬 $)+$ finasteride $(5 \alpha-\mathrm{RI})$ が よい成績を収めているとの追加報告 ${ }^{22}$ がなされた. また新しい $5 \alpha$-RI である dutasteride も登場してお

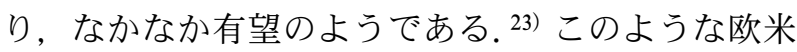
の状況に対して，わが国ではなぜか $5 \alpha-R I$ は市販 されておらず，この方面の開拓が進まないことは気 がかりである.

\section{OAB と BPH}

2002 年の国際禁制学会 (ICS) 総会で OAB の概 念が提唱され, ${ }^{2)}$ わが国でも既に独立した疾患単位 として認められるようになった。 OAB とは尿意切 
迫感を主体とする症候群であり，多くは頻尿を伴 い，失禁は約半数に認められる. OAB の原因とし ては神経因性膀胱によるもの以外では，特発性，老 化，BPH/BOO などが挙げられている。実際， $\mathrm{BPH}$ の症状のうち，患者が最も悩むものは $\mathrm{OAB}$ の症状であるとも言われている.

では，なぜ BPH で OAB が出現するのか. 完全に はこの発生機序は解明されていない。最近は，膀胱 組織と尿とを隔てている尿路上皮の関与が注目され ている，尿路上皮は移行上皮からなり，従来は膀胱 の単なるバリアと考えられていた。しかしながら現 在は，BPH/BOO などによって膀胱に負荷がかか り移行上皮が伸展すると，尿路上皮から ATP， prostaglandin (PG), NO, セロトニン (5-HT)，ア セチルコリン（Ach）などが分泌され，それらが正 常では休眠状態にある膀胱の $\mathrm{C}$ 繊維といわれる求 心性知覚神経の興奮性を惹起し，これが蓄尿時の膀 胱の感覚を過敏にし，OAB を引き起こすと考えら れている．また，膀胱平滑筋そのものにも伸展によ る変化が起こり，そこから分泌される Ach, ATP, NGF といった物質，あるいは平滑筋接合部の異常 や，平滑筋に分布する神経の変化が，膀胱平滑筋の 収縮性を六進するとも考えられている (Fig. 4).24)

今のところ，BPH に起因する OAB の治療に は，他の原因による $\mathrm{OAB}$ と同様，抗コリン薬を $\alpha_{1}$
遮断薬とともに用いている。OAB の主な原因であ る，Ach の働きを抑えることが症状改善に有効と 考えるからである．現在，日本において開発あるい は使用されている代表的な抗コリン薬を Table 4 に 示す。

従来，抗コリン薬は膀胱の平滑筋を弛緩して排尿 困難を助長し，場合によっては尿閉を引き起こして しまう恐れがあり，BPH には禁忌とされてきた。

しかしながら $\alpha_{1}$ 遮断薬との投与時間差を設け，低 活動膀胱には使わないようにするなど，十分注意工 夫して慎重に投与すれば，安全に治療を続けられ る. ${ }^{25)}$ 現在 $\alpha_{1}$ 遮断薬と抗コリン薬の大規模併用試 験が進行しておりその結果が待たれる．いずれにし ても安易に抗コリン薬を BPH 治療に使用すること だけは避けるべきであろう。今後，OAB の原因究

Table 4. Anti-cholinergic Agents for OAB 過活動膀胱に使用される抗コリン剂

\begin{tabular}{ll}
\hline \hline 一 般 名 & \multicolumn{1}{c}{ 商 品 名 } \\
\hline プロパンテリン & プロバンサイン \\
フラボキサート & ブラダロン \\
オキシブチニン & ポラキス \\
プロピベリン & バップフォー \\
トルテロジン & 海外のみ（日本 : 申請中） \\
ソリフェナシン & 海外のみ（日本 : 申請中） \\
イミダフェナシン & 申請中 \\
\hline
\end{tabular}

過活動膀胱の発生における膀胱知覚神経系の役割

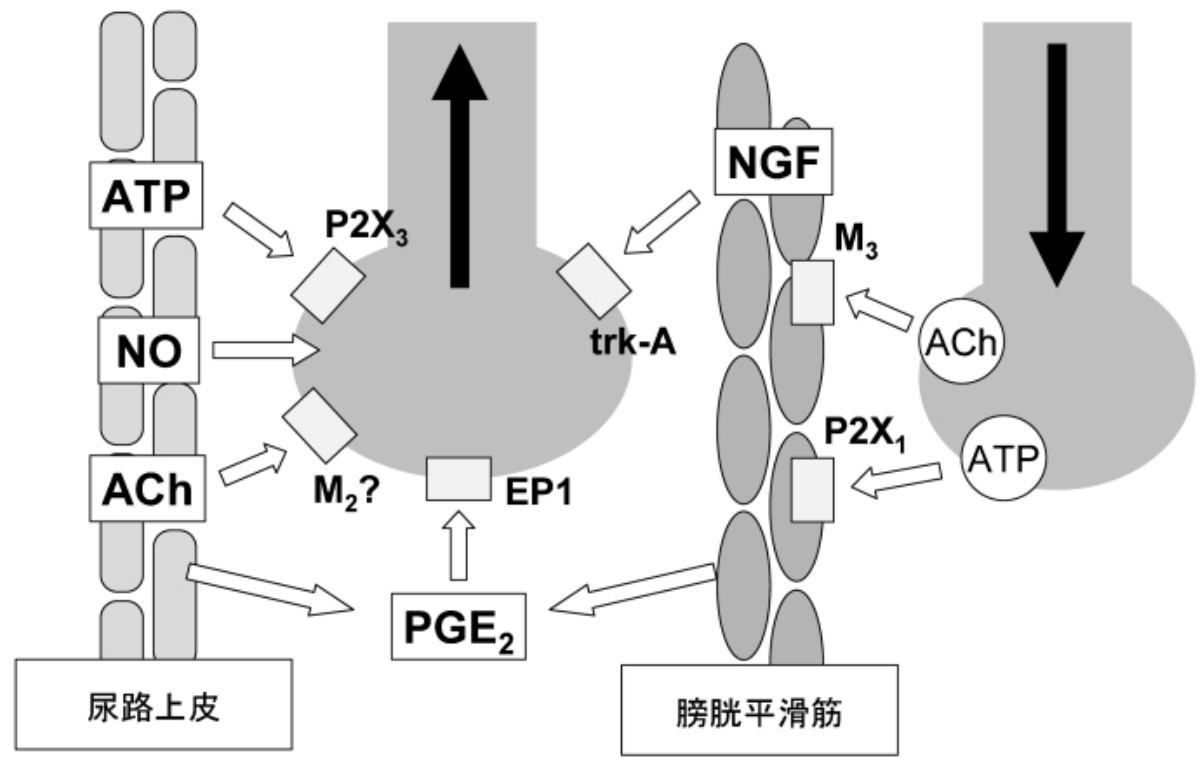

Fig. 4. The Role of Bladder Sensory Nerve on the Pathogenesis of Overactive Bladder. 
明が進み，他の治療薬も開発され，より根本的な治 療法が開発されることが期待される.

\section{7. 新しい研究の流れ}

2005 年の日本泌尿器科学会総会では, 除神経性 の膀胱刺激状態に有効と思える薬物の紹介があっ た. ${ }^{26)}$ 前述の抗コリン薬にしても，副作用のより少 ない，より膀胱に特異的なものができてくる可能性 がある．抗コリン薬の作用部位は膀胱のムスカリン 受容体 $\left(\mathrm{M}_{2}\right.$ と $\mathrm{M}_{3}$, 特に $\left.\mathrm{M}_{3}\right)$ が主なものと考えら れる，さらに，前立腺そのものに存在するムスカリ ン受容体への作用も無視できない. ${ }^{27)} \alpha_{1}$ 遮断薬で は，先に述べたような，前立腺に対する作用に加え て, 膀胱血流の改善作用や尿道求心性知覚神経に働 く作用も考えられている．また，エンドセリン及び その受容体 $\mathrm{ET}_{\mathrm{A}}$ が， $\mathrm{BPH}$ による $\mathrm{OAB}$ に関与する ことも報告された。したがって， $\mathrm{ET}_{\mathrm{A}}$ 拮抗薬は， $\mathrm{BPH}$ 症状のうち最も治療に難渋する $\mathrm{OAB}$ 症状に 対する有用性が示唆された。 ${ }^{28)} さ ら に ，$ 膀胱に豊富 に存在する $\beta_{3}$ 受容体をターゲットとした $\beta_{3}$ 刺激薬 も開発されており, ${ }^{29,30)} \mathrm{BPH}$ に付随する OAB 症状 を含めた膀胱機能改善に効果が期待される．ただ し，いずれも現在のところは動物実験段階であり， 臨床的検証が今後の課題であろう.

8. おわりに

前立腺や膀胱についての薬理学的研究が進んで, 治療薬は格段の進歩を遂げた。とはいえ，やはり手 術に頼らなければならないケースが存在することも 確かである. 手術が何らかの理由でできないとき， いわば薬物療法と手術療法の中間に位置するような 方法も開発されている。例えば，前立腺内へのアル コール注入やボッリヌストキシンの注入法であ る. ${ }^{31,32)}$ 前者は組織壊死を引き起こすのであろう し，後者は神経の変性を誘発するのであろう.

泌尿器科医のような外科系の医師にとつて, 手術 を減らす薬物療法はかならずしも歓迎すべきではな いかもしれない。しかし, 薬物療法の発展と相まっ て排尿機構の解明が加速され, 結果的に手術に頼ら ないで済むようになつたのなら，医学薬学の進歩に よる必然として受容しなければならないことである。

\section{REFERENCES}

1) Homma Y., Kawabe K., Tsukamoto T., Yamaguchi O., Okada K., Aso Y., Watanabe
H., Okajima E., Kumazawa J., Yamaguchi T., Ohashi Y., Int. J. Urol., 3, 267-273 (1996).

2) Abrams P., Cardozo L., Fall M., Griffiths D., Rosier P., Ulmsten U., van Kerrebroeck P., Victor A., Wein A., Neurourol. Urodyn., 21, 167-178 (2002).

3) Gerber G. S., Fitzpatrik J. M., BJU Int., 94, 338-344 (2004).

4) Vela-Navarrete R., Escribano-Burgos M., Farre A. L., Garcia-Cardoso J., Manzarbeitia F., Carrasco C., J. Urol., 173, 507-510 (2005).

5) Oki T., Suzuki M., Nishioka Y., Yasuda A., Umegaki K., Yamada S., J. Urol., 173, 13951399 (2005).

6) Nakamura Y., Tsujimoto G., Tanoue A., Ikegaki I., Shiozaki S., Nimura T., Matsuda Y., Kawatani M., Abstracts of papers, the 34th Annual Meeting of the Joint Meeting of the International Continence Society and the International UroGynecological Association, Paris, August 2004, No. 77, p. 508.

7) Takei R., Ikegaki I., Shibata K., Tsujimoto G., Asano T., Jpn. J. Pharmacol., 79, 447454 (1999).

8) Chen Q., Takahashi S., Zhong S., Hosoda C., Zheng H. Y., Ogushi T., Fujimura T., Ohta N., Tanoue A., Tsujimoto G., Kitamura T., J. Urol., 174, 370-374 (2005) .

9) Matsukawa Y., Gotoh M., Kamihira O., Ono Y., Ohshima S., Abstracts of papers, the 100th Annual Meeting of the American Urological Association, San Antonio, May 2005, No. 1702, p. 461a.

10) Foglar R., Shibata K., Horie K., Hirasawa A., Tsujimoto G., Eur. J. Pharmacol., 288, 201207 (1995).

11) Shibata K., Foglar R., Horie K., Obika K., Sakamoto A., Ogawa S., Tsujimoto G., Mol. Pharmacol., 48, 250-258 (1995).

12) Yoshida M., Kawabe K., Homma Y., Abstracts of papers, the 100th Annual Meeting of the American Urological Association, San Antonio, May 2005, No. 1642, p. 445a.

13) Kawabe K., Homma Y., Kubota K., Sozu T., Int. J. Urol. (in press).

14) Akino H., Maekawa M., Shioyama R., Ishida Y., Oyama N., Miwa Y., Yokoyama O., Ab- 
stracts of papers, the 11th Annual Meeting of the Japanese Neurogenic Bladder Society, Tokyo, October 2004, No. 46, p. 101.

15) Ichioka K., Ohara H., Terada N., Matsui Y., Yoshimura K., Terai A., Arai Y., Int. J. Urol., 11, 870-875 (2004).

16) Paick S. H., Meehan A., Lee M., Penson D. F., Wessells H., J. Urol., 173, 903-907 (2005).

17) Narayan P., Bruskewitz R., Adv. Ther., 17, 287-300 (2000).

18) Hisasue S., Furuya R., Itoh N., Kato R., Kobayashi K., Takeyama K., Kitamura H., Suzuki K., Honma I., Shimizu T., Hashimoto K., Takahashi A., Matsukawa M., Masumori N., Furuya S., Tsukamoto T., Abstracts of papers, the 100th Annual Meeting of the American Urological Association, San Antonio, May 2005, No. 1069, p. 290a.

19) Foster H. E., Yono M., Shin D., Takahashi W., Latifpour J., Abstracts of papers, the 100th Annual Meeting of the American Urological Association, San Antonio, May 2005, No. 1440, p. 390a.

20) Lepor H., Williford W. O., Barry M. J. Brawer M. K., Dixon C. M., Gormley G., Haakenson C., Machi M., Narayan P., Padley R. J., N. Engl. J. Med., 335, 533-539 (1996) .

21) McConnell J. D., Roehrborn C. G., Bautista O. M., Andriole Jr. G. L., Dixon C. M., Kusek J. W., Lepor H., McVary K. T., Nyberg Jr. L. M., Clarke H. S., Crawford E. D., Diokno A., Foley J. P., Foster H. E., Jacobs S. C., Kaplan S. A., Kreder K. J., Lieber M. M., Lucia M. S., Miller G. J., Menon M., Milam D. F., Ramsdell J. W., Schenkman N. S., Slawin K. M., Smith J. A., N. Engl. J. Med., 349, 2387-2398 (2003).

22) Kaplan S. A., Roehrborn C. G., Lee M. W., Abstracts of papers, the 100th Annual Meeting of the American Urological Association, San Antonio, May 2005, No. 1636, p. 443a.
23) Roehrborn C. G., Marks L. S., Fenter T., Freedman S., Tuttle J., Gittleman M., Morrill B., Wolford E. T., Urology, 63, 709-715 (2004).

24) Yokoyama O., Akino H., Miwa Y., Oyama N., Yusup A., Aoki Y., Ishida Y., Shioyama R., Nakai M., Maekawa M., Kusukawa N., Yamauchi H., Voiding Disorders Digest, 12, 297-303 (2004).

25) Athanasopoulos A., Gyftopoulos K., Giannitsas K., Fisfis J., Perimenis P., Barbalias G., J. Urol., 169, 2253-2256 (2003).

26) Liu F., Takahashi N., Yamaguchi O., Suzuki K., Yamada M., Abstracts of papers, the 93rd Annual Meeting of the Japanese Urological Association, Tokyo, April 2005, No. OP2018, p. 227a.

27) Abdel-khalek M., El-Baz M., Nabieh A., Ibrahiem E. H., Abstracts of papers, the 100th Annual Meeting of the American Urological Association, San Antonio, May 2005, No. 1455, p. 394a.

28) Yuyama H., Ukai M., Noguchi Y., Someya A., Watanabe M., Okutsu H., Yoshino T., Ohtake A., Suzuki M., Sato S., Sasamata M., Abstracts of papers, the 100th Annual Meeting of the American Urological Association, San Antonio, May 2005, No. 1446, p. 392a.

29) Igawa Y., Yamazaki Y., Takeda H., Hayakawa K., Akahane M., Ajisawa Y., Yoneyama T., Nishizawa O., Andersson K. E., Br. J. Pharmacol., 126, 819-825 (1999).

30) Takeda H., Yamazaki Y., Akahane M., Igawa Y., Ajisawa Y., Nishizawa O., J. Pharmacol. Exp. Ther., 293, 939-945 (2000).

31) Goya N., Ishikawa N., Ito F., Kobayashi C., Tomizawa Y., Toma H., J. Urol., 172, 10171020 (2004).

32) Maria G., Brisinda G., Givello I. M., Bentivoglio A. R., Sganga G., Albanese A., Urology, 62, 259-264 (2003). 